\title{
Penerapan Metode Demonstrasi Menggunakan Kartu untuk Meningkatkan Prestasi Belajar Operasi Penjumlahan dan Pengurangan pada Peserta Didik Kelas I di SDN 2 Sobo Kecamatan Munjungan Kabupaten Trenggalek
}

\author{
Dhami \\ SDN 2 Sobo Kecamatan Munjungan Kabupaten Trenggalek, Indonesia \\ Email: dhamisobo1968@gmail.com
}

\begin{abstract}
Abstrak: Meskipun sebagian siswa sudah mendapatkan pelajaran atau pengalaman dalam berhitung, namun tidak semua siswa menguasai materi operasi penjumlahan dan pengurangan. Pemilihan metode atau cara mengajar termasuk salah satu pengaruh kesulitan dalam menangkap materi yang disampaikan guru. Oleh karena itu, penelitian ini bertujuan untuk meningkatkan hasil belajar Operasi Penjumlahan dan Pengurangan Pada Peserta Didik Kelas I SD menggunakan metode demontrasi menggunakan kartu. Penelitian ini termasuk penelitian tindakan kelas dengan dua siklus. Hasil penelitian ini menunjukkan bahwa nilai

Tersedia Online di

http://journal.unublitar.ac.id/pendidi

kan/index.php/Riset_Konseptual

Sejarah Artikel

Diterima pada : 18-01-2020

Disetuji pada : 29-01-2020

Dipublikasikan pada : 31-01-2020

\section{Kata Kunci:}

metode demostrasi, kartu, operasi

penjumlahan dan pengurangan

DOI:

http://doi.org/10.28926/riset_konseptual.v4i 1.189 tertinggi yang dicapai pada siklus I dan siklus II adalah sama yakni 100. Sedangkan nilai terendah yang dicapai oleh siswa pada siklus I adalah 50 dan pada sikl;us II adalah 60 . Terdapat peningkatan nilai 10 dan nilai rata-rata pada siklusn I adalah 72 dan pada siklus II sebesar 82. Terdapat peningkatan 10. Selanjutnya ketuntasan klasikal, pada siklus I sebesar $64 \%$ dan pada siklus II mencapai 93\%. Terjadi peningkatan 29\%. Dengan demikian dapat disimpulkan bahwa penerapan metode demonstrasi menggunakan kartu efektif untuk meningkatkan prestasi siswa dalam materi operasi penjumlahan dan pengurangan.
\end{abstract}

\section{PENDAHULUAN}

Siswa kelas I Sekolah Dasar merupakan sosok individu yang masih sangat rentan dalam perkembangan emosional atau psikisnya. Untuk itu guru harus dapat benar-benar mempengaruhi siswa, memikat siswa, sehingga siswa dapat menyukai mata pelajaran Matematika. Jika pada usia ini siswa sudah mempunyai rasa takut terhadap Matematika, maka sampai besarpun biasanya rasa takut itu akan terbawa.

Melihat sedikit urian tersebut, tentunya juga berkaitan dengan guru yang mengajar. Menjadi guru kelas I SD seringkali dihindari oleh para guru pada umumnya. Bukan karena tidak mampu, tetapi memerlukan upaya ekstra dalam menghadapi siswa. Guru kelas I harus memiliki karakter yang sabar, telaten, dan mampu membaur dalam dunia siswa. Dengan demikian akan terjalin hubungan psikologis yang kuat antara guru dengan siswa. Ikatan psikologis inilah yang kemudian dapat membawa siswa dalam situasi belajar yang nyaman dan tenang. Jika kondisi psikologis siswa sudah nyaman, tentunya konsep yang dipelajari juga dapat dipahami dengan mudah.

Matematika merupakan salah satu mata pelajaran yang dianggap sulit oleh siswa, sehingga pada pembelajaran Matemaika keberanian siswa seringkali hilang. Untuk itu diperlukan suatu teknik yang dapat membangkitkan keberanian siswa serta teknik yang dapat memotivasi siswa untuk belajar. 
Penelitian ini diawali dengan kegiatan pra penelitian (pra siklus). Tahap pra siklus, siswa mempelajhari materi "Bilangan Cacah." Pada tahap ini siswa banyak yang kurang berhasil atau prestasi belajarnya rendah. Beberapa hal yang dapat disampaikan sebagai hasil pengamatan tahap pra siklus menunjukkan siswa kurang keberanian pada saat pembelajaran berlangsung. Banyak siswa yang menundukkan kepala atau bersembunyi di balik tubuh temannya. Selain itu, guru kurang memotivasi siswa dan metode yang dipergunakan mungkin juga kurang menarik siswa.

Sesuai dengan hasil yang dicapai pada rahap pra siklus, guru mencari solusi tentang bagaimana sebaiknya melakukan pembelajaran berikutnya. Dari hasil pemikiran tersebut kemudia gru menentukan bahwa pembelajaran berikutnya akan dilakukan dengan menerapkan metode pembelajaran yang sangat mengaktifkan siswa, yakni dengan metode demonstrasi. Melalui metode ini diharapkan siswa dapat menghilangkan rasa takutnya, karena siswa akan beraktifitas aktif dan menyenangkan.

Berdasarkan uraian di atas, maka penelitian ini bertujuan untuk meneliti "Penerapan Metode Demonstrasi Menggunakan Kartu untuk Meningkatkan Prestasi Belajar Operasi Penjumlahan Dan Pengurangan Pada Peserta Didik Kelas I di SDN 2 Sobo Kecamatan Munjungan Kabupaten Trenggalek Semester 1 Tahun Pelajaran 2018/2019". Metode demonstrasi adalah metode mengajar yang sangat efektif, karena dapat membantu peserta didik untuk melihat secara langsung proses terjadinya sesuatu. Metode demonstrasi adalah cara penyajian bahan pelajaran dengan memperagakan atau mempertunjukkan kepada peserta didik suatu proses, situasi atau benda tertentu yang sedang dipelajari baik sebenarnya atau tiruan yang sering disertai penjelasan lisan.

Metode demonstrasi adalah : "Metode mengajar di mana seorang guru atau orang lain yang sengaja diminta peserta didik sendiri memperlihatkan kepada seluruh anak di dalam kelas, suatu kaifiyah melakukan sesuatu." (Anissatul Mufarokah. 2009:50). Metode demonstrasi adalah metode mengajar dengan cara memperagakan barang, kejadian, aturan, dan urutan melakukan suatu kegiatan, baik secara langsung maupun melalui penggunaan media pengajaran yang relevan dengan pokok bahasan atau materi yang sedang disajikan (Muhibbin Syah, 2000:22).

Penelitian dengan tema yang sama telah banyak dilakukan oleh penelitipeneliti sebelumnya seperti Widowati (2011) yang meneliti penggunaan metode demonstrasi menggunakan kartu untuk operasi penjumlahan bilangan bulat. Hasil penelitan tersebut menunjukkan bahwa data menunjukkan bahwa hasil belajar siswa pada pra tindakan rata-rata 20,0. Pada siklus I mencapai 62,7 , sedangkan pada siklus II mencapai rata-rata 80,0 sehingga ketuntasan belajar meningkat melampaui standar ketuntasan minimal $75 \%$. Muslimin (2019) juga meneliti tema yang sama namun pada tingkat sekolah menengah pertama. Hasil penelitiannya menunjukkan bahwa nilai ratarata kelas eksperimen yaitu 76.26 > nilai rata-rata kelas kontrol yaitu 65,88. Maka hipotesis diterima atau ada perbedaan antara hasil belajar dengan metode demonstrasi menggunakan media kartu dan hasil belajar menggunakan strategi pembelajaran ekspositori pada pokok bahasan penjumlahan dan pengurangan pada bilangan bulat di kelas VII SMP Negeri 10 Palembang. Asmulik (2016) juga meneliti tema yang sama namun diterapkan pada siswa di Madrasah Tsanawiyah. Hasilnya menunjukkan bahwa nilai rata-rata pada siswa Kelas I Madrasah Ibtidaiyah Kamulan Kecamatan Durenan Kabupaten Trenggalek sebelum siklus: 70,53 dengan ketuntasan belajar sebesar $42,11 \%$, pada siklus I: 77,11 dengan ketuntasan belajar naik menjadi $52,63 \%$ dan siklus II: 87,63 dengan ketuntasan belajar mencapai $89,47 \%$. Dengan demikian dapat disimpulkan penggunaan metode demonstrasi tersebut efektif diterapkan.

Tujuan penelitian ini untuk mendapatkan gambaran objektif mengenai peningkaan prestasi belajar operasi penjumlahan dan pengurangan pada peserta didik kelas I di SDN 2 Sobo Kecamatan Munjungan Kabupaten Trenggalek semester 1 tahun pelajaran 2018/2019 setelah menerapkan metode demonstrasi dengan 
menggunakan kartu. Dari hasil penelitian ini diharapkan siswa dapat belajar dengan suasana yang lebih menyenangkan, lebih aktif, sehingga dapat menghilangkan atau menguranagi rasa takut pada diri siswa. Tenangnya kondisi spikologis siswa dapat enunjang keberhasilannya dalam meraih prestasi belakjar yang maksimal.

\section{METODE}

Penelitian ini merupakan penelitian tindakan kelas (PTK). Sesuai dengan namanya, penelitian ini merupakan penelitian tinbdakan. tentunya hal tersebut merupakan ciri khusus dari penelitian ini, yang membedakannya dengan penelitian yang lain. Untuk lebih memahami mengenai apa yang dimaksud dengan Penelitian Tindakan Kelas (PTK), berikut adalah kutipannya.

"Penelitian Tindakan Kelas adalah suatu bentuk penelitian yang bersifat reflektif dengan melakukan tindakan-tindakan tertentu untuk memperbaiki dan meningkatkan praktik pembelajaran di kelas secara lebih berkualitas sehingga siswa dapat memperoleh hasil belajar yang lebih baik " (Mohammad Asrori, 2011:6).

Penelitian ini dilakukan dalam jangka waktu 3 bulan,vdari pra siklus sampai selesainya penyusunan laporan, yakni pada akhir bulan Agustus 2018 sampai dengan Oktober 2018.

Setiap siklus penelitian terdiri dari empat tahapan, yang meliputi planning (rencana), action (tindakan), observation (pengamatan), dan reflection (refleksi). Kemmis dan Taggart menyampaikan bahwa alur PTK adalah :

Gambar 1 Alur Penelitian dari Kemmis dan Taggart (1992)

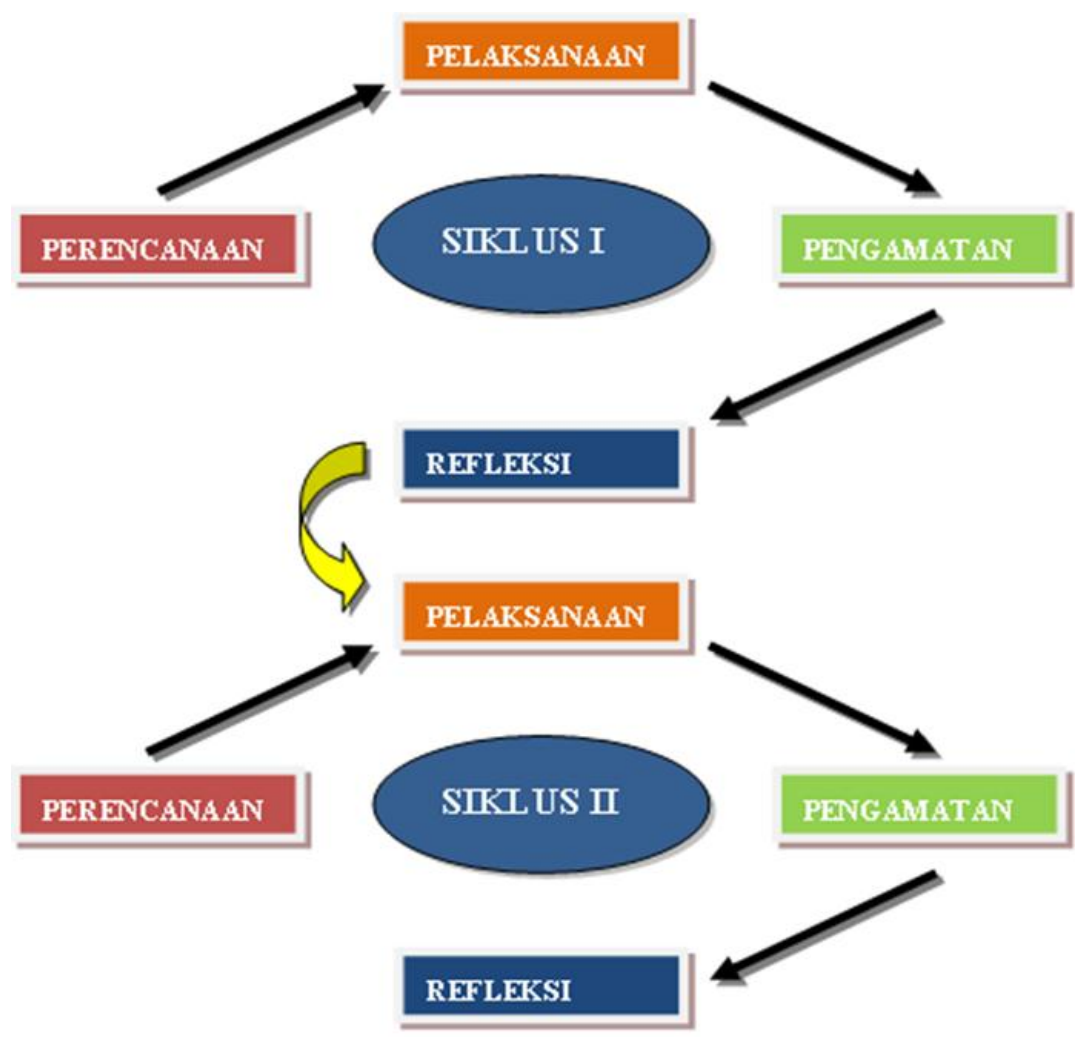




\section{HASIL DAN PEMBAHASAN}

\section{Kondisi Awal ( Pra Siklus)}

Hasil test pra siklus menunjukkan hasil sebagai berikut.

Tabel 1. Kualifikasi Nilai Test Akhir Pra Siklus

\begin{tabular}{|c|c|c|c|c|c|c|c|}
\hline Nilai & $\mathrm{f}$ & $\%$ & $\mathrm{~N} \times \mathrm{F}$ & Tuntas & $\%$ & $\begin{array}{c}\text { Tidak } \\
\text { Tuntas }\end{array}$ & $\%$ \\
\hline 100 & 1 & 4 & 100 & 17 & 61 & 11 & 39 \\
\hline 90 & 3 & 11 & 270 & & & & \\
\hline 80 & 4 & 14 & 320 & & & & \\
\hline 70 & 9 & 32 & 630 & & & & \\
\hline 60 & 6 & 21 & 360 & & rt2 & 67 & \\
\hline 50 & 5 & 18 & 250 & & & & \\
\hline \multicolumn{7}{|l|}{ Nilai Tertinggi : 100} \\
\hline
\end{tabular}

Hasil penillaian atau tes pra siklus menunjukkan sebanyak 17 siswa (61\%) tuntas dalam belajar. Prosentase terbesar berada pada nilai 70 sebanyak $32 \%$, kemudian nilai 60 sebanyak $21 \%$, nilai 50 sebanjak 18\%, nilai 80 sebanyak 14\%, nilai 90 sebanyak $11 \%$, dan prosentase terendah pada nilai 100 sebanyak $4 \%$.

Ketuntasan kelas masih mencapai $61 \%$ sementara yang disyaratkan adalah minimal $70 \%$. Dengan demikian maka pembelajarah siklus I perlu direfleksi, dicarikan solusi agardapat memenuhi kriteriaa ketuntasan kelas yang disyaratkan.

Hasil refleksi dari pelaksanaan pra siklus adalah :

1. Siswa kurang keberanian pada saat pembelajaran berlangsung. Banyak siswa yang menundukkan kepala atau bersembunyi di balik tubuh temannya.

2. Guru kurang memotivasi siswa dan metode yang dipergunakan mungkin juga

kurang menarik siswa.

\section{Siklus 1}

Pada tahap perencanaan siklus I materi yang dibahas adalah SK 4 yaitu melakukan penjumlahan dan pengurangan bilangan sampai dua angka dalam pemecahan masalah dan KD 4.1 tetang penjumlahan dan pengurangan bilangan

Indikator "Penjumlahan sampai dengan 20."

KKM Matpel sebesar 70. KKM Kelas sebesar 70.

Perencanaan siklus I pertemuan 1 dilaksanakan sebagai berikut:

1) Guru membuat RPP

2) Guru menyusun LKS

3) Guru menentukan media pembelajaran

4) Guru membuat Daftar Hadir Siswa

5) Guru menyusun soal test akhir

Pelaksanaan tindakan dilakukan oleh guru dengan menerapkan model pembelajaran demonstrasi, sebagaimana yang terdapat pada RPP. Adapun langkahlangkahnya adalah sebagai berikut:

Guru menyampaikan kompetensi yang ingin dicapai, yakni penjumlahan sampai dengan 20. Setelah siswa dirasa siap mengikuti pembelajaran, guru menyiapkan bahan atau alat yang diperlukan yakni kartu. Dengan media kartu tersebut, guru mendemonstrasikan cara-cara menyelesaikan masalah yang berkaitan dengan penjumlahan sampai dengan 20. Selanjutnya, siswa secara bergantian mendemonstrasikan cara menyelesaikan operasi hitung di depan kelas. Siswa yang 
laon memperhatikan. Setelah dirasa cukup, guru memberikan penekanan materi dan menyampaikan pesan-pesan untuk pertemuan 2 .

Pada tahap siklus I pertemuan I ini, siswa belajar dalam suasana yang kurang cair, masih vacuum, dan masih banyak siswa yang merasa takut untuk melakukan demonstrasi.

Pelaksanaan tindakan dilakukan oleh guru dengan menerapkan model pembelajaran demonstrasi, sebagaimana yang terdapat pada RPP. Karena pembelajaran dilakukan pada jam ke-tiga, maka tanpa mengucap salam pembuka, guru langsung menyampaikan bahan pengait dan mengingatkan tugas yang akan dilakukan pada pertemuan 2 sebagaimana yang disampaikan pada akhir pertemuan 1 . Pada pertemuan 2 kegiatan inti dibuka dengan pemberian soal-soal latihan kepada siswa. Selesai mengerjakan soal latihan, guru mengajak siswa untuk mengambil kesimpulan. Selanjutnya, untuik mengetahui tingkat keberhasilan, guru mengadakan tes akhir secara mandiri dan pada tahap akhir guru menutup pembelajaran dengan mengadakan refleksi.

Hasil pengamatan guru selama kegiatan pembelajaran berlangsung menunjukkan aktifitas siswa yang semakin meningkat, tetapi masih sangat rendah. Siswa dapat menerjakan soal secara mandiri walaupun masih terlihat tengok kiri tengok kanan karena rasa kurang percaya diri.

Tabel 2. Penilaian Hasil Evaluasi Akhir Siklus 1

\begin{tabular}{|c|c|c|c|c|c|c|c|}
\hline Nilai & $\mathrm{f}$ & $\%$ & $\mathrm{~N} \mathrm{x} \mathrm{F}$ & Tuntas & $\%$ & $\begin{array}{c}\text { Tidak } \\
\text { Tuntas }\end{array}$ & $\%$ \\
\hline 100 & 5 & 18 & 500 & 18 & 64 & 10 & 36 \\
\hline 90 & 4 & 14 & 360 & & & & \\
\hline 80 & 3 & 11 & 240 & & & & \\
\hline 70 & 6 & 21 & 420 & & & & \\
\hline 60 & 6 & 21 & 360 & & & & \\
\hline 50 & 4 & 14 & 200 & & & & \\
\hline \multicolumn{7}{|l|}{} \\
\hline
\end{tabular}

Berdasarkan tabel di atas, nilai tertinggi yang dapat dicapai oleh siswa adalah 100. Nilai terendah 50 , dan nilai rata-rata kelas sebesar 72 Siswa tuntas mencapai $64 \%$, meningkat 3\% dari pra siklus. Dari $64 \%$ tersebut, nilai 60 dan 70 menjadi modus karena memperoleh prosentase tertinggi yakni 21\%, kemudian nilai 100 dicapai oleh 18\% siswa, nilai 90 dan 50 masing-masing dicapai oleh 14\% siswa, dan frekuensi terendah yang dicapai siswa adalah nilai 80 sebajyak $11 \%$. Mengingat hasil yang dicapai oleh siswa belum dapat mencapai tingkat ketuntasan kelas minimal $70 \%$, maka pembelajaran belum dapat dikatakan berhasil.

Setelah dilaksanakan tahap siklus I yang terdiri dari dua pertemuan, dapat disampaikan refleksi sebagai berikut: "Keberanian siswa mulai meningkat, walaupun rasa percaya dirinya masih sangatb kurang. Nilai yang dicapai oileh siswa juga meningkat namun belum mampu mencapai KKM kelas yang ditentukan."

\section{SIKLUS II}

Pelaksanaan tindakan dilakukan oleh guru dengan menerapkan model pembelajaran demonstrasi dengan menggunakan kartu, sebagaimana yang terdapat pada RPP. Adapun langkah-langkahnya adalah sebagai berikut: guru menyampaikan kompetensi yang ingin dicapai, yakni pengurangan sampai dengan 20. Setelah siswa dirasa siap mengikuti pembelajaran, guru menyiapkan bahan atau alat yang diperlukan 
yakni kartu, piring, tanda pengurangan (-), tanda sama dengan (=), dan angka. Dengan media kartu tersebut, guru mendemonstrasikan cara-cara menyelesaikan masalah yang berkaitan dengan pengurangan sampai dengan 20. Selanjutnya, siswa secara bergantian mendemonstrasikan cara menyelesaikan operasi hitung pengurangan di depan kelas. Siswa yang lain memperhatikan.

.Setelah dirasa cukup, guru memberikan penekanan materi dan menyampaikan pesan-pesan untuk pertemuan 2. Pengamatan dilakukan pada saat pembelajaran berlangsung. Pada tahap siklus II pertemuan I ini, siswa dapat belajar dengan situasi yang menyenangkan. Dari wajah siswa tidak terlihat rasa takut, tetapi justru menunjukkan keberanian yang luar biasa. Mereka berebut angkat tangan agar ditunjuk untuk melakukan demonstrasi.

Hasil pengamatan guru selama kegiatan pembelajaran berlangsung menunjukkan aktifitas siswa yang sangat baik, penuh percaya diri dan aktif dengan tidak menyimpang dari kegiatan belajar. Walaupun mereka melaksamalam kegiatan be;lajar dengan demonstrasi, tetapi mereka belajar dengan sungguh-sungguh dan tidak bermain sendiri.

Tabel 3. Penilaian Hasil Evaluasi Akhir Siklus II

\begin{tabular}{|c|c|c|c|c|c|c|c|}
\hline Nilai & $\mathrm{F}$ & $\%$ & $\mathrm{~N} \times \mathrm{F}$ & Tuntas & $\%$ & $\begin{array}{c}\text { Tidak } \\
\text { Tuntas }\end{array}$ & $\%$ \\
\hline 100 & 7 & 25 & 700 & 26 & 93 & 2 & 7 \\
\hline 90 & 4 & 14 & 360 & & & & \\
\hline 80 & 6 & 21 & 480 & & & & \\
\hline 70 & 9 & 32 & 630 & & & & \\
\hline 60 & 2 & 7 & 120 & & & & \\
\hline 50 & 0 & 0 & 0 & & & & \\
\hline \multicolumn{7}{|l|}{} \\
\hline \multicolumn{7}{l}{ Nilai Tertinggi : 100} \\
\hline
\end{tabular}

Pada akhir siklus II dilakukan penjajakan terhadap daya serap siswa dengan mengadakan tes akhir. Hasil sebagaimana yang terdapat pada tabel di atas menunjukkan bahwa siswa tuntas mencapai $90 \%$. Dari jumlah tersebut, prosentase tertinggi berada pada nilai 70 sebanyak $31 \%$, kemudian nilai 100 sebanyak $25 \%$, nilai 80 sebanyak $21 \%$, dan nilai 90 sebanyak 14\%. Pada siklusn II ini tidak ada lagisiswa yang memperoleh nilai 50 .

Tabel 4. Rekap Hasil Tes Akhir Siklus I dan Siklus II

\begin{tabular}{|l|l|l|l|l|}
\hline Siklus & \multicolumn{4}{|c|}{ Aspek } \\
\cline { 2 - 5 } & Nilai Tertinggi & Nilai Terendah & $\begin{array}{c}\text { Nilai } \\
\text { Rata- } \\
\text { Rata }\end{array}$ & $\begin{array}{c}\text { Ketuntasan } \\
(\%)\end{array}$ \\
\hline $\mathrm{I}$ & 100 & 50 & 72 & 64 \\
\hline $\mathrm{li}$ & 100 & 60 & 82 & 93 \\
\hline
\end{tabular}

Berdasarkan rekapitulasi perolehan tes akhir siswa sebagaimana yang disampaikan di atas, dapat diketahui bahwa nilai tertinggi yang dicapai pada siklus I dan siklus II adalah sama yakni 100 . Sedangkan nilai terendah yang dicapai oleh siswa pada siklus I adalah 50 dan pada siklus II adalah 60. Terdapat peningkatan nilai 10. Nilai rata-rata pada siklus I adalah 72 dan pada siklus II sebesar 82. Terdapat peningkatan 10 . Ketuntasan klasikal, pada siklus I sebesar $64 \%$ dan pada siklus II mencapai 93\%. Terjadi peningkatan 29\%. Sesuai dengan hasil yang diperoleh 
tersebut, maka dapat dinyatakan bahwa model pembelajaran demonstrasi dapat membantu siswa dalam meningkatkan prestasi belajarnya. Kiranya hal tersebut sangat masyk akal dan tidak mustahil karena belajar dengan demonstrasi mempunyain tingkat kognitif yang cukup tinggi, disbanding hanya sekedar mendengarkan.

\section{KESIMPULAN}

Hasil analisis data yang selanjutnya dipergunakan sebagai acuan untuk mengambil kesimpulan diketahui bahwa nilai tertinggi yang dicapai pada siklus I dan siklus II adalah sama yakni 100. Sedangkan nilai terendah yang dicapai oleh siswa pada siklus I adalah 50 dan pada siklus II adalah 60. Terdapat peningkatan nilai 10 dan nilai rata-rata pada siklusn I adalah 72 dan pada siklus II sebesar 82. Terdapat peningkatan 10 . Selanjutnya ketuntasan klasikal, pada siklus I sebesar $64 \%$ dan pada siklus II mencapai 93\%. Terjadi peningkatan 29\%. Dengan demikian dapat disimpulkan bahwa penerapan metode demonstrasi menggunakan kartu dapat meningkatkan prestasi belajar operasi penjumlahan dan pengurangan pada peserta pidik kelas I di SDN 2 Sobo Kecamatan Munjungan Kabupaten Trenggalek Semester 1 Tahun Pelajaran 2018/2019".

\section{DAFTAR RUJUKAN}

Ali, Mohammaddan Mohammad Asrori. (2011). Psikologi Remaja dan Perkembangan Peserta Didik. Jakarta: Bumi Aksara.

Anissatul Mufarokah. (2009). Strategi Belajar Mengajar. Yogjakarta: Teras.

Asmulik. (2016). Peningkatan Prestasi Belajar Materi Penjumlahan Dan Pengurangan Pada Bidang Studi Matematika Dengan Menerapkan Metode Belajar Demonstrasi Pada Siswa Kelas I Semester li Tahun 2013/2014 Madrasah Ibtidaiyah Kamulan Kecamatan Durenan Trenggalek. Jurnal Pendidikan Profesional. Volume 5, No. 1, April 2016

Muhibbin, Syah. (2000). Psikologi Pendidikan Dengan Pendekatan Baru. Bandung: Remaja Rosdakarya

Muslimin, Sunardi, dan Shaumi. (2019). Pengaruh Media Kartu terhadap Hasil Belajar Matematika Siswa di Kelas VII SMP Negeri 10 Palembang. Edumatica. Volume 09 Nomor 01 April 2019

Kemmis, S \& Mc Taggart, R. (1992). The Action Research Planner. Australia: Deakin University Press.

Widowati, Ruri Ayu. (2011). Penerapan metode demonstrasi menggunakan kartu bilangan bulat untuk meningkatkan hasil belajar matematika dalam menyelesaikan penjumlahan bilangan bulat pada siswa kelas IV SDN Kebotohan Pasuruan. Tugas Akhir (Sarjana)--Universitas Negeri Malang, TA Program Studi S1 PJJ PGSD. 2011 